\title{
ON THE DISTURVANCE ON THE HEARING AND THE VESTIBULAR FUNCTION BY KANAMYCIN
}

\author{
By
}

\author{
Y. NOSAKA, M. SADANAGA, T. IDATE AND R. KANZAKI
}

From the Department of Oto-Rhino-Laryngology, Medical School of Kumamoto University. (Director: Prof. Y. Nosaka)

Out of 19 patients who had been taking Kanamycin two suffered from subjective by-effects of deafness, tinnitus and urticaria, respectively, and one vertigo and the rest 14 patients suffered from no by.effect at all.

By the audiogram disturvances were found in 14 patients (73.7\%), 57.2\% of which were in both sides of the ear. The amounts of dose, by which the deafness was caused, were 5 85g, mostly under 50g, and the deafness began within a period of 3 months. The degree of disturvance was in most cases slight with hearing loss of no more than $30 \mathrm{db}$, and only 3 ears had hearing loss of 35 45db. The type of audiogram was mostly the gradual form, but the abrupt and the dip forms were also found. The region of the disturvance gradually increased at 2,000c.p.s. and most of cases were disturbed in high tones above 6,000c.p.s. In the use of medicine doses of less than $4 \mathrm{~g}$. per week there was no sign of regular tendency, but deafness was found among patients who were suffering from disorder in liver.

The vestibular function showed no change in the Goniometry and the post-rotatory nystagmus test and yet there were some instances of small tendency of increase in the caloric nystagmus, but nothing significant was found in all.

\section{カナマイシンの聴力並に前庭機能障碍に就て}

熊本大学医学部耳悬咽㘈科学教室

\begin{tabular}{|c|c|c|c|c|c|c|c|}
\hline 授 & 野 & 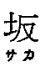 & $\begin{array}{l}\text { 保 } \\
十 \text { 十 }\end{array}$ & 次・大学院学生 & 定 & $\begin{array}{c}\text { 永 } \\
\neq \neq t\end{array}$ & 正 \\
\hline 大学院学 & 井 & 妾示 & 俱 & 睦 ・大学院学生 & $\begin{array}{l}\text { 神 } \\
\infty=\end{array}$ & 崎 & 龍 \\
\hline
\end{tabular}

カナマイシン (以下 $\mathrm{KM}$ ) は梅沢博士が長野県の土懐 試料から分離した放線菌 Streplomyces, Kanamyceticus の産生する新しい抗生物質であつて，グラム陽性菌 及び陰性菌, 更に抗酸性菌にる抗菌作用を有して抗菌ス ペクトルが広い，即ち各種の急性感染症に奏効するが， 就印他㮔薬剂に而性となつた葡萄球菌又は赤痢菌，大腸 菌感染が多くなつた現在では本郕に頙著な効果が期待さ れる。

更に結核症に対しては動物実驗（柳沢）に打いても， 臨床実験に扎いてもストレプトマイシン (SM) に匹敵 する効果を示し，ことに SM, INAH, PAS 耐性結核 菌による感染に対しても感受性菌の場合と同樣に弮效す ると云われている・従って結核症治療に一つの新しい有
カな棐剤が登場し前途を更に明るくしている。

さて本剂にも副作用として好酸球の増加, 尿中硝子様 円柱の出現が認められてはいるが，㛙れも臨床上大きな 意義はなく，最も重要なものは SM 㚣び DHSM と同 様に第 8 脳神経侄対する障碍である。

KM の聴器障碍については堂野前, 市川及び Finland が綜合研究あるいは日米合同の KM シンポデアムKお いて言及しているに過ぎず詳細な報告は見当らない，我 々は本剂の聴覚障碍の予防と治療に資する目的で，まず

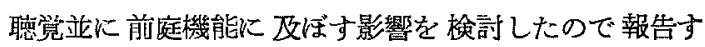
る。

調查症例並に方法

症例は熊大第 1 内科及び熊本自治病院入院中の肺結核 
患者19名である・使用矤は KM 硫酸塭 $1 \mathrm{~g}$ (力価) を 蒸溜水 $3 \mathrm{ml}$ に溶解し，凡气 1 日量 $1 \sim 2 \mathrm{~g}$ を1日2回分 割で週2〜3 日筋肉注射した・しかし症例によつては1日 量 3〜2〜1g と聥減したるのや, 週 4 日あるいは隔日投 与した例子各 1 例ある.

これ等患者に就て KM 治療開始前に聴力並に前庭機 能検查を実施し，その後毎月 1 回宛症状の許す限りその 变動を追求した.Audiogram は当教室無第室に执いて NY 裴 51-A IV 型 Audiometerを用いた。聴力障碍 の判定には2 ケ処以上の音閶に特いて $10 \mathrm{db}$ 以上の損失 をきたしているものを低下とした．文前庭機能は䫟倒角

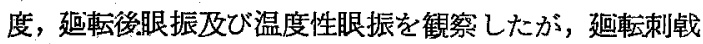
は主に Bárány の強刺㦸法を, 一部に Kobrak の弱刺

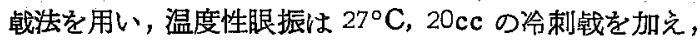
眼振持続時間，振盪回数を参照した.

\section{調 查 成 績}

1)自覚症状

$\mathrm{KM}$ 療法夷施によつて何等かの副作用を自営した者 は4/19 名で $21.1 \%$ を示し，難聴，耳鳴，菱麻疹 (Dermatographie) 夫ょ2, 眩最 1 となっている. しびれ感， 頭重感等は認めなからた。

2) 難聴儿就て

難恥出現率 他覚的難聴は 14/19名 73.7\%の高率汇現 れた. しかも片耳.障碍は 42.8\%で，耐耳性が $57.2 \%$ で や〉多い．従つて耳数では $23 / 38$ 耳で $60.5 \%$ の難聴出現 率となる。

難聴の程度 凡そ $30 \mathrm{db}$ 損失迄の軽度難聴が 20/23耳 で 86.9\%を占め， 60db 損失迄の中等度難聴は $3 / 23$ 耳 13.1\% 亿過ざず，それも35 45db 程度である・高度難 聴は認めない。

聴力型 最低可聴䦪值の聴力曲線は第 1 表の如く，斜 降型が $9 / 23$ 耳で $39.1 \%$ を占め最も多く, $8000,10000 \mathrm{cps}$ の障碍 4 耳が次ざ，急烈型（5 例中 3 例は既往に SM 使 用し当初上り)， dip 型 $(6000 \mathrm{cps}), 3000 \mathrm{cps}$ 以上の障 碍の他，水平型む1 1 耳認められている。

周波数別の 障碍部位（第 2 表） $2000 \mathrm{cps}$ から高音閾 に障碍頻度が次第に渐堌するが，特に 6000cps 以上殊 に $8000 \mathrm{cps}$ で顕著に侵される。低音閾のみの障碍は認 めなからた。

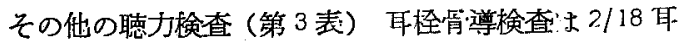
のみが陰性で，他は 14/18 耳が陽性である. D.L. test は15/16耳が(+)で，1耳のみ（一）であつたが，こ の陰性例では耳柽骨尊検查は陽性であった。 又 Balance
第 1 表

\begin{tabular}{|c|c|c|}
\hline 耻力型 & 耳呚 & SM RER \\
\hline 钭降䧳 & 9 & $6 / 4$ \\
\hline 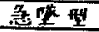 & $5 \%$ & $3 / 5$ \\
\hline$d i p+1$ & $2(60006 \mathrm{cos}$ & $2 / 2$ \\
\hline $8000,10000 t$ & 4 & $y / 4$ \\
\hline $3000 \sim \downarrow$ & 2 & $\%$ \\
\hline * 平 和 & 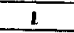 & $\%$ \\
\hline
\end{tabular}

*この中 3 耳仿当初ょり

第 2 表 周波数別の㜔碍部位

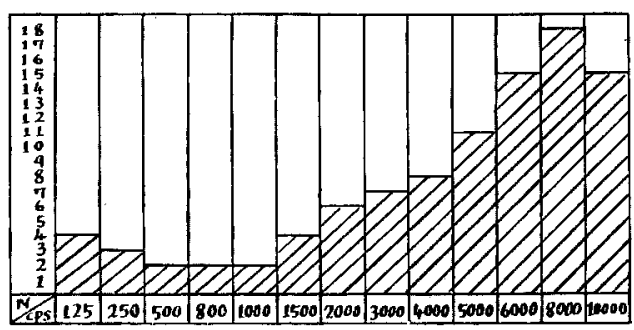

第 3 表

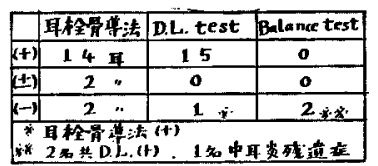

test は2例に就て実施可能であつたが熟れる陰性であ つた・しかしこの2例共 D.L. test（ト）であり，1名 は中耳:炎残遗症を有し，他の 1 名には伝音器障碍はなか つた.

次に KM 難聴症例に就て各種条件より観察を試みよ 弓.

年令的関係・各年代別比就て見ると

$\begin{array}{llll}10 \text { 才台 } & 3 / 4 & 40 \text { 才台 } & 2 / 3 \\ 20 \text { 才台 } & 3 / 3 & 50 \text { 才台 } & 2 / 2 \\ 30 \text { 才台 } & 3 / 6 & 60 \text { 才台 } & 1 / 1\end{array}$

の如く，著しい頻度差はないが，50 才台以上は頻発する 上5に思われ，10才台には漸く障碍例に入る程度の軽微 なものも含まれている。

使用量，方法との関係（第4表）1日2g 使用例炕が 障碍耳数の頻度がや>多く，且つ中等度難聴 3 ，例中２例 が含まれている. 1 週の投与回数でに 2 週法より 3 週法 が却つて少く，週 $4 \mathrm{~g}$ 以内では一定の傾向㲜譛めない 難㯖を起した初発量 第5表の如く既に $5 \mathrm{~g}$ 及び $9 \mathrm{~g}$ で障碍を起した例るあるが，20g 台から增加し，40g 台 で最も多い. 即ら $50 \mathrm{~g}$ 迄にが多発しているが，85g で も起つている例があり，個人的素因の差が大きい。 難聴発現迄の其嫺 
第 5 表

第 4 表

\begin{tabular}{|c|c|c|}
\hline \multicolumn{3}{|c|}{ 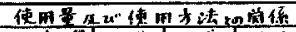 } \\
\hline IA 值明量 & 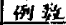 & 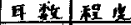 \\
\hline $3 y \rightarrow 24-14$ & Z100\% & 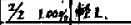 \\
\hline 24 & $1 / 45 \%$ & $5 / 3$ astitin 12 \\
\hline 14 & $3 / 4114 \%$ & $18253.621+84.1$ \\
\hline 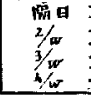 & $\begin{array}{l}\% \\
5 / 4 \\
5 / 8 \\
1 / 1\end{array}$ & $\begin{array}{r}88.9 \% \\
62.5 \% \\
200.0+ \\
\end{array}$ \\
\hline
\end{tabular}

第 6 表

\begin{tabular}{|c|c|c|c|c|}
\hline \multicolumn{5}{|c|}{ 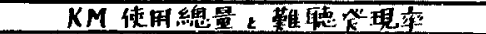 } \\
\hline 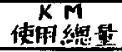 & 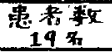 & 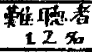 & 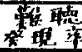 & \\
\hline $0 \sim 10 \mathrm{~g}$ & 0 & 0 & & \\
\hline-20 . & $\mathbf{0}$ & 0 & & \\
\hline-30. & $\boldsymbol{2}$ & $\mathbf{l}$ & $50 \%$ & \\
\hline$-40 \ldots$ & 3 & 3 & 100 & $n$ \\
\hline$\sim 50$ & 3 & 1 & 33 & " \\
\hline$-60 \%$ & 3 & 2 & 67 & . \\
\hline-70. & 3 & 1 & 33 & - \\
\hline-80. & 1 & 1 & 100 & . \\
\hline-90. & 2 & 1 & 50 & " \\
\hline$-100 \ldots$ & 1 & 1 & 100 & - \\
\hline $100 \sim$ & 1 & 1 & $100-$ & - \\
\hline
\end{tabular}

$\begin{array}{llll}\text { 1月後 } & 3 & 4 \text { 月後 } & 1 \\ 2 \text { 月後 } & 4 & 5 \text { 月後 } & 1 \\ 3 \text { 月後 } & 3 & 6 \text { 月後 } & 2\end{array}$

1 月後に起つている例が3例あり，大体 3 力月後迄に が多いが，6カ月後にも発現している。

使用総量と 難聴発現率 $20 \mathrm{~g}$ 迄には難聴の 発現はな く，30g上り現れ，特に $80 \mathrm{~g}$ 以上では比現度が大きい (第6 垡).

使用中止挠: 経過 $\mathrm{KM}$ 使用中止後 4 力月挠と6 6 月 挠に夫ま1例聴打低下゙きたているが，孰れも使用中 止前に起つた難聴の増悪で共に $20 \mathrm{db}$ 上内の軽い低下で ある・

$$
\begin{aligned}
& 4 \text { 力月後 } \begin{cases}\mathrm{L} & 10 \sim 20 \mathrm{db} \text { 低下 } \\
\mathrm{r} & 10 \mathrm{db} \text { 低下 }\end{cases} \\
& 6 \text { 力月後 } \begin{cases}\mathrm{L} & 15 \mathrm{db} \text { 低下 } \\
\mathrm{r} & 10 \sim 15 \mathrm{db} \text { 以下 }\end{cases}
\end{aligned}
$$

SM 暊使用との関係 SM ぬ前に注射した症例は9 名中 5 名 (55.6\%) に $\mathrm{KM}$ 難恥をさたして扣るのに対 し，非使用群は9/10名90.0\%に難聴をさたして特り却 つて非使用群にが多発しているが見えるが，その程度 は前者に中等度難聴が 2 名, 挠:老に 1 名である。

留, 旰機能障碍との関係 尿中の蛋白, 糖, ウロビリ ノーゲン等孰れる著变を認めず，本剂によると思われる
腎譏能異常は認めなかつた・

肝機能に就ては高田反応，Gros 反応，Meulengracht 法，ブロムサルフアレン試験及び血清蛋白量を測定し綜 合判定で $2 / 17$ 例が侵され，肝機能中等度障碍者でり中 等度難聴，軽度障碍者では軽度難聴が夫る諗められ，そ の関連性が深われる。

3）前庭機能障碍に就乙（第 7 表）

Goniometry では㒛查全例に KM 投与前後に殆えと 傾角度の差を誑めなかつた。画転後眼振では 1/8例にや 〉堌强が見られ，2 例は 2 回目测定時にや〉低下し次に や」堌強が見られた，温度性眼振は前後:の検查可能であ つた例では敦れる堌強が見られた。しかし温度性眼振増 強例は共に廷転挠腿振に変化なく，臨床的に機能障淂と 云う程度のるのは見当らない。

\begin{tabular}{|c|c|c|c|c|c|}
\hline \multicolumn{6}{|c|}{ 前庭科能检查 } \\
\hline & 阵名 & Gon. & 建等右眼振 & 温意栍昨诚 & SM \\
\hline 1 & 松充 & 不 变 & 不 & 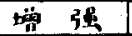 & $(-)$ \\
\hline 2 & 村上 & 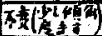 & 不 妾 & & $(-)$ \\
\hline 3 & 里崎 & 下变 & 稍《䏆强 & t要 39 & $(-1)$ \\
\hline 4 & 藤本 & 不妾 & 2ET & & $1-1$ \\
\hline 5 & 莣木 & 不亦 & 稍，增强 & & $(+1)$ \\
\hline 6 & $4 a$ & 王常 & IE 常 & 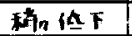 & $(-1)$ \\
\hline 7 & 姑原 & 正常 & 劳 & 正 掌 & $(-1)$ \\
\hline 8 & 西早田 & F变 & 不 & 稍橧强 & $\sqrt{1+1}$ \\
\hline
\end{tabular}

第 7 表

\section{紷括並びに考按}

KM の毒性殊に第 8 脳神経系に及ばす障碍に関して は梅沢，Dickison 及び Robinson 等の動物夷験があ る・梅沢は猫を用いて毎日 $300 \mathrm{mg} / \mathrm{kg}$ の長期投与の害 験で SM より遭動失調で示される姜性は低く，文正円 密から誘尊される動作電流による試験でる聴神経系に効 し SM より毒性が低い等を確認している. 又梅沢及び Dickison は条件反射で同じ強さの音で繩を登るよらに 訓練したラットに KM 300〜200 $\mathrm{mg} / \mathrm{kg}$, DHSM 200 $\mathrm{mg} / \mathrm{kg}$ を毎日注射して観察した処，KM 群では6週後 にも变化はなからたが DHSM 群では5週目には2/6 近，6週目には5/6 匹が条件反射を起すに強い音を必要 として捛り（挴沢），又 DHSM では3週後音の大さを 大にする事が必要で，KM では4週後僅かばかり音を 大きくする事が必要であつたとしている (Dickison). Robinson はラットK 112 1200mg/kg の KM, 100〜 $200 \mathrm{mg} / \mathrm{kg}$ の Neomycin, 200 $800 \mathrm{mg} / \mathrm{kg}$ の DHSM を毎日注射して 20000cps の音 (Galton 笛) に䴔する Startle 反応を検查して，KM は Neomycin に比して 
聴覚障碍は少いが，DHSM よりは本実駼並に猫を用い た成績でもや大であると云う．更に Robinson は渠 理学的传 Streptomyces, kanamyceticus $4 \mathrm{KM}$ の主 成分である KM A の他に KM B を作るが，特に B を除去しなからた $\mathrm{KM}$ の製品では $\mathrm{A}$ よりも実騟的に 㖵聴を起し易いと述べている.

平衡障碍に関しても前記の如く猫の毎日 $\mathrm{KM} 300 \mathrm{mg}$ $/ \mathrm{kg}$ 投与 21 日で運動障碍む雪気試験による前庭機能る 障碍が無いのに，SM $(100 \mathrm{mg} / \mathrm{kg}) 14$ 日注射では運動 障碍並炕前庭障碍を起しており (梅沢)，Dickison む 平衡障碍は $\mathrm{SM}$ が $\mathrm{KM}$ よりも著しい㮫を明かにてて いる:

又臨床成結では堂野前は 1 週 $6 \mathrm{~g}$ 上下の投与量では 88 例中自党的難聴は全くなく, オージオメトリーで 3 例 (3\%) に聴力低下を認め， $6 \mathrm{~g}$ 以上投与群では $7 / 40$ 例 18 $\%$ \% $6000 \mathrm{cps}$ 以上の高音闒に $20 \mathrm{db}$ 以上の損失を， $6000 \mathrm{cps}$ 以下で2例 (5\%) に低下を認めているが，特 に $8000 \mathrm{cps}$ の障碍が顕著であると云う.市川は6例に 聴力障碍を認め多くは連日投与の際に見られ高音部障碍 で， $50 \mathrm{~g}$ 上下の使用で聴力障碍の起つた 2 例には高度の 腎機能障碍があつたと云つている. McClement はシム ボジアムで 1 日量 $0.5 \sim 1.0 \mathrm{~g}$ 使用 $2 \sim 4 \mathrm{t} / 2$ 月で 17 例全例 にオージオグラム上の変化を認めている.

さて我々の調查では，KM 難聴は 2 ケ外以上の音闒で $10 \mathrm{db}$ 以上の損失を判定の規準とすれば73.7\% に聴力低 下が見られた・しかむ両耳性が半数以上であつたが，難 聴の程度は大部分が 軽度であり，中等度の難聴は $13 \%$ に過ざず且つ $45 \mathrm{db}$ 程度であつた・聴力型は䣄降型が最 も多く $6000 \mathrm{cps}$ 以上の高調音障碍が著しく特に 8000 cps が影著であつた。使用量との関係では1日 $2 \mathrm{~g}$ 使用 例にか゚ $1 \mathrm{~g}$ に比して障碍の頻度, 程度共に大であつた が，1 週の投与回数では週 $4 \mathrm{~g}$ 以内では一定の傾向は認

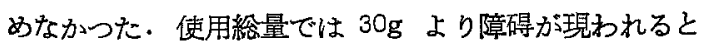
云5 Bunn の成績と一致し， $8 \mathrm{Cg}$ 以上では著しく多発 している・これに就て市川は30〜70g 使用では7〜8\% に，80〜99g では14\%に，100g 上上では全例に起ると しており，総量を堌せば聴力障碍は当然増加の傾向をき たす.しかし難聴を起した初発量に就ては $50 \mathrm{~g}$ 迄にが 多発てて郝るが，5g でも起つた例があり，DHSM と 同様本肪孔個人的感受性の差が著しい，難聴発現迄の期 間では凡そ 3 月後迄に多いが 6 力月後迄にも見られ る・睌発性の嚾聴に就ては Finland は SM やNM の 如く注射を止めてから難聴の起つた例は無いと云つてい
るが，我々の例では使用中止前に起つたいた難㯖が中止 後 $20 \mathrm{db}$ 以内の軽い低下をきたしたものは認められた。 既往の SM 使用と KM による難聴の発現との関係で は，非使用群にが瀕発しており本剤に感受性が高いるの と思われる・又筒機能とは泌展器結核を対象とした市川 の如き関遭性は認められなからた・しかし肝機能障㥂者 灘聴の程度が大であつた事检味がある。従来肝機能 と聴力障碍に関しては Wolfheim, 药池 (三) 等が着目 した奶であり，笑験的にもこれを実証する業績例えば内 耳液のアシニン，アスパラギン酸の減少が高音障碍をき たし(後落修)，あるいは神経性難聴では血中ニレステ ロールが堌量して障碍を起すと云う報告もある(Pick). 更に久保 (浩) 等も肝疾患の過半数汇 高音閵の無自営性 聴力障碍を招き，その程度は肝機能と平行し，且っ SM 難聴に潜在性肝機能障碍が高率に出現すると云う・即ち

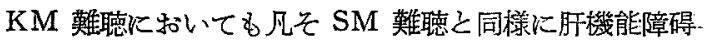
による新陳代謝異常及び血行障碍等が関与しているもの であろう・な括 KM による難聴は前記のォージオグラ ム及び大部分が耳柽骨尊検查並に D.L. test で陽性で ある笔から感音系殊に主として内耳性障碍に基くもので あろうと考える。

又自覚症状に就ては本調查では $10.5 \%$ 目鳴を訴元た が，堂野前の 23\%，Finland の耳鳴をもつて難聴出現、 の警我警報であるとする報告よりも頻度は眇い。眩量に 就ては 1 例のみこれを訴光，堂野前 $0.5 \%$ の瀕度と同率: であつた・

前庭機能障碍に就ては臨床例で 1 例軽い前庭機能障碍 が認められている(堂野前)・本調査では Goniometry で全例 $\mathrm{KM}$ 投与前後に鱝倒角度の差異を認めず，笑験 的眼振では温度性眼振に多少増強が筧われたが，臨床上 機能障碍と称し得る程度のむのは認めなかつた。即ち SM に比較して KM の前庭神経への毒性は軽いものと 思われる。

以上 $\mathrm{KM}$ の副作用としての㯖覚器並に平衡覚器に及 ぼす影響に就て晸告したが，難聴発現の予防法に就ては 今後の研究に俟ちたい。

\section{結論}

使用患者 19 名中自覚的副作用は難聴，耳鳴，罸麻疹 夫ょ2, 眩最1であり，何等の副作用を訴兄ない者が 14 名であつた・

Audiogram では14 名 (73.7\%) に障碍を認め, 57.2 \%は両側性であつた・難聴をきたす迄の初発使用量は 5 〜85g で，50g 迄にが多発しており，期間では 3 カ月後 
迄にが多い. 障碍程度は $30 \mathrm{db} \cdot$ 損失以内の軽度難聴が殆 んどで 35〜 45db 損失は 3 耳に過ぎない. 聴力型は斜降 型が多く，急墜型， dip 型も見られた・部位は $2000 \mathrm{cps}$ から漸増し $6000 \mathrm{cps}$ 以上の高調音障碍が多い。使用法 との䦭係は週 $4 \mathrm{~g}$ 以下では一定の傾向を認めないが，肝 機能障䅞者に難聴が見られた～

前庭機能は䝿倒序度, 迴転後腿振で变化なく, 温度性 眼振で多少堌強の傾向ある例もあつたが，概して著变を 諰めなかつた。

\section{文献}

1) H. Umezawa, M. Ueda, K. Maeda, K. Yagishita, S. Kondo, Y. Okami, R. Utahara, Y. Osato, K. Nitta \& T. Takeuchi: J. Antibioticus. 10, 181 (1957).

2) K. Maeda, M. Ueda, K. Yagishita, S. Kawag?, S. Kondo, M. Murase, T. Takeushi, Y. Okami \& H. Umezawa: J. Antibioticus, 10, 228 (1957). 3) T. Takeushi, T. Hikiji, K. Nitta, S. Yamazaki, S. Abe, H. Takayama \& H. Unezawa: J. Antibioticus. 10, 107 (1957). 4) H.L. Dickison, D.E. Tish \& J.B.
Huftoleon: 目本医㑂会雑誌，39,715 (1958). 9) H.J. Robinson, A.K. Miller \& O.E. Graessle: 由茠 医師会雑点, 39,727 (1958).

6) 堂野祯: 日本医 研会雑誌, 39, 734 (1958).

7）市刜：日本医師会 雑誌，39, 730 (1958). 8) P.A. Bunn: 日本医即 会雑䛠, 38, 732 (1958).

9) 堂野前，五昧，宝来， 具田, 河合, 河盛, 北本, 阿藤, 嗍, 島村, 砂原: 日本

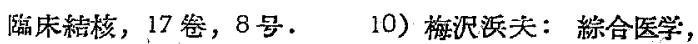
14卷, 12昂. 11) Finland: カナマイシン・シンポ

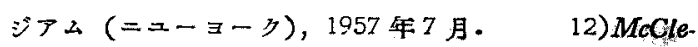

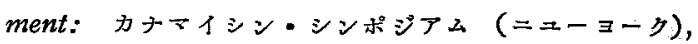
1957 年 7 月. 13) 久保沿一, 他: 日耳墏, 61 卷, 辞特号.

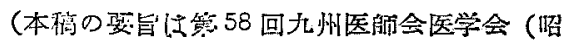
和33等10月）によ゙て発装した。)

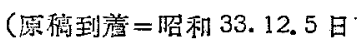

